\title{
PENGARUH HASIL BELAJAR MATA PELAJARAN PRODUKTIF, KEMAMPUAN BERKOMUNIKASI DAN SIKAP WIRAUSAHA TERHADAP MINAT WIRAUSAHA PADA SISWA SMK NEGERI SURABAYA
}

\author{
Nur Chabiba, Universitas Negeri Surabaya \\ nurchabiba223@yahoo.co.id
}

\begin{abstract}
ABSTRAK
Penelitian ini bertujuan mengetahui pengaruh hasil belajar mata pelajaran produktif, kemampuan berkomunikasi dan sikap wirausaha terhadap minat wirausaha pada siswa SMKN Surabaya tahun pelajaran 2014-2015. Populasi sebanyak 391 dan sampel menggunakan teknik probability sampling sebanyak 80. Penelitian ini menggunakan pendekatan kuantitatif tingkat eksplanasi dengan teknik analisa regresi linier dan data dikumpulkan dengan kuesioner dan dokumentasi. secara parsial hasil belajartidak mempunyai pengaruh signifikan positif terhadap minat wirausaha, Kemampuan berkomunikasi mempunyai pengaruh signifikan positif terhadap minat wirausaha, Sikap Wirausaha memiliki pengaruh secara parsial terhadap minat wirausaha, Kesimpulannya secara simultan hasil belajar mata pelajaran produktif, kemampuan berkomunikasi, dan sikap wirausaha memiliki pengaruh terhadap minat wirausaha.
\end{abstract}

Kata Kunci : Hasil Belajar Mata Pelajaran Produktif, Kemampuan Berkomunikasi, Sikap Wirausaha dan Minat Wirausaha

\begin{abstract}
This study aims to determine The Effect of Learning Outcomes On productive lesson, communication ability and Entrepreneurship behaviour Towards Interest of Entrepreneurship by Students at SMKN in Surabaya year 2014 - 2015. The population of as many as 391 and samples with sampling using probability sampling as many as 80 . Data collected by questionnaire and documentations. Partially, the Learning Outcomes has no positive and signifficant Effect for Entrepreneurial interest. The conclusion is Communication Skills has a signifficant Influence for Entrepreneurial interest. Entrepreneurship behaviour has a signifficant effect partially on Entrepreneurial Interest. It can be concluded that simultanously, learning outcomes on productive lesson, communication skills, and entrepreneurial behaviour have an influence on the entrepreneurial interest.

Keywords: Learning outcomes at productive lesson, Communication Skills, Entrepreneurial behaviour and Entrepreneurial Interests.
\end{abstract}

\section{PENDAHULUAN}

Jumlah pengangguran di Kota Pahlawan atau Surabaya masih tinggi itu 
membuat keprihatinan tersendiri bagi warga Surabaya. Kemajuan kota yang pesat tak diimbangi dengan penyediaan lapangan pekerjaan yang cukup. Kota ini adalah kota besar dengan APBD yang lebih dari Rp5,7 triliun," ujar Ketua Komisi C DPRD Surabaya Sachiroel Alim Anwar, Minggu (21/7/2013) pada Surya Online. Ia melanjutkan, ada juga tambahan pengangguran dari kalangan perempuan. Jumlah ibu rumah tangga yang tidak bekerja sebesar 542.998 orang dan pelajar atau mahasiswa 462.738 orang. Jumlah seluruhnya sekitar 1,7 juta orang. Sehingga lebih dari separuh penduduk Surabaya ini belum bisa dikategorikan mandiri dan masih bergantung pada orang lain. Kondisi seperti ini sebenarnya sudah terjadi sejak 2010 lalu, namun hingga sekarang angka pengangguran masih belum banyak mengalami penurunan.

Angka pengangguran di Indonesia cukup tinggi, yakni 7,7 juta jiwa dari total jumlah penduduk 250 juta jiwa. Pengangguran terbesar terdapat di Jawa yakni 66 persen, disusul Sumatera 18 persen, Kalimantan 5 persen, Papua dan NTB dibawah 5 persen. Hal ini diungkapkan Dirjen Pendidikan Anak Usia Dini, Non Formal dan Informal (Paudni) Kemendikbud Prof Dr Lydia Freyani Hawadi di sela pembukaan Jobfair Selaras Dikdudi 2014 di SMKN 2 Surabaya, Sabtu (25/1/2014).

Tingginya angka pengangguran ini salah satunya disebabkan karena kebanyakan mereka berharap menjadi pegawai negeri sipil (PNS) ataukaryawan swasta. Jarang sekali yang memutuskan untuk berwirausaha.hampir 250 juta penduduk Indonesia, yang berwirausaha hanya 0,28 persen. Fenomena yang terjadi berkenaan dengan wirausaha, mereka yang berwirausaha ini pendidikannya umumnya seperti SD dan SMP. Jarang sekali sarjana atau SMA/SMK yang memilih berwirausaha khususnya di SMK Negeri 1, 4 dan 10 Surabaya. Sehingga pengangguran justru banyak pada lulusan SMA/SMK dan sarjana. Untuk menekan angka pengangguran ini, salah satu upayanya melalui program penyelarasan dunia pendidikan dengan dunia usaha dan dunia industri (selaras Dikdudi), berupa jobfair. Jobfair ini menjembatani lulusan SMK atau pendidikan nonformal dengan pasar kerja.

Pengangguran dan kemiskinan masih menjadi permasalahan di Indonesia. Menurut Saiman (2009) Pengangguran dan kemiskinan terjadi karena perbandingan antara jumlah penawaran kesempatan kerja tidak sebanding dengan jumlah lulusan atau penawaran tenaga kerja baru di segala level pendidikan. Namun, jumlah pengangguran dan kemiskinan sebenarnya dapat diperkecil dengan keberanian membuka usaha-usaha baru atau berwirausaha. Sehingga dengan berwirausaha merupakan salah satu cara pembangunan perekonomian negara Indonesia agar lebih baik dan maju.

Pembangunan perekonomian akan lebih berhasil jika ditunjang oleh wirausahawan yang dapat membuka lapangan kerja karena kemampuan pemerintah sangat terbatas. Pemerintah tidak akan mampu menggarap semua aspek pembangunan karena sangat banyak membutuhkan anggaran belanja, personalia dan pengawasan. Oleh karena itu, wirausaha merupakan potensi pembangunan, baik dalam jumlah maupun dalam mutu wirausaha itu sendiri.

Menurut Slameto (2010), minat adalah rasa lebih suka dan rasa ketertarikan pada suatu hal atau aktivitas, tanpa ada yang menyuruh. Minat pada dasarnya adalah penerimaan akan suatu hubungan antara diri sendiri dengan sesuatu di luar diri. Semakin kuat atau dekat hubungan tersebut, 
semakin besar minatnya.. Minat momentan ialah perasaan tertarik pada suatu topik yang sedang dibahas atau dipelajari untuk itu kerap digunakan istilah "perhatian". Perhatian dalam arti "minat momentan", perlu dibedakan dari perhatian dalam arti "konsentrasi", sebagaimana dijelaskan di atas. Antara minat dan berperasaan senang terhadap hubungan timbal balik, sehingga tidak mengherankan kalau siswa yang berperasaan tidak senang, akan kurang berminat, dan sebaliknya. Berdasarkan paparan tentang pengertian minat, maka dapat disimpulkan bahwa minat adalah rasa ketertarikan pada suatu hal atau aktivitas tanpa ada paksaan dan merasa senang untuk mempelajarinya. Rasa ketertarikan tersebut bukan karena paksaan tapi kesadaran yang tinggi karena keinginan yang kuat untuk mencapai tujuannya.

Minat berwirausaha di Kota Surabaya ini mempunyai peluang yang besar untuk dikembangkan. Menurut data dari BPS selama periode enam tahun terakhir PDRB per sektor lapangan usaha kota Surabaya mengalami peningkatan di segala sektor. Yang memiliki nilai terbesar dan peningkatan yang sangat signifian adalah sektor perdagangan, hotel, dan restoran. Badan Pusat Statistika Kota Surabaya,Propinsi Jawa Timur mengalami pertumbuhan ekonomi sebesar 7,22 \% dimana nilai tersebut melebihi pertumbuhan ekonomi nasional yang hanya sebesar $6,46 \%$. Sedangkan Kota Surabaya memilliki pertumbuhan ekonomi yang lebih tinggi dibandingkan dengan Propinsi Jawa Timur.

Kontribusi PDRB Surabaya terhadap Jawa Timur terbesar berasal dari sektor perdagangan, hotel, dan restauran (43,31\%); sektor industri dan pengolahan $(22,18 \%)$; pengangkutan dan komunikasi $(9,86 \%$; dan keuangan, persewaan, dan jasa-jasa $(7,76 \%)$.

Menurut Bygrave (Alma, 2013), Entrepreneur is the person who perceives an opportunity and creates an organization to persueit. Berdasarkan definisi tersebut seorang wirausaha adalah orang yang melihat adanya peluang kemudian menciptakan sebuah organisasi untuk memanfaatkan peluang tersebut.Hal tersebut menunjukan bahwa wirausaha tidak hanya mengandalkan modal saja.

Minat berwirausaha sebaiknya dikembangkan mulai dari remaja. Hal ini dikarenakan mereka sebenarnya memiliki ide-ide yang masih baru dan kreatif. Oleh karena itu peran Sekolah Menengah Kejuruan (SMK) mempunyai peluang untuk mengembangkan kewirausahaan dan membangun perekonomian dengan memanfaatkan tahap perkembangan remaja ditandai dengan adanya minat yang makin mantap terhadap fungsi-fungsi intelek. Selain itu sekolah berperan besar dan strategis dalam mengubah sikap siswa dari mencari kerja menjadi pencipta lapangan kerja (wirausaha). Menurut Peraturan Pemerintah No.66 Tahun 2010, Sekolah Menengah Kejuruan (SMK) merupakan salah satu bentuk pendidikan formal kejuruan pada jenjang pendidikan menengah. SMK merupakan pendidikan menengah kejuruan sebagai lanjutan SMP/ MTs atau bentuk lain yang sederajat/diakui sama/setara SMP atau MTs.SMK adalah lembaga pendidikan kejuruan yang tujuan utamanya mempersiapkan siswa menjadi tenaga kerja yang andal. Oleh karena itu lulusan SMK diharapkan tidak hanya bekerja di industri saja tetapi dapat mengembangkan potensi dalam dirinya untuk bekerja mandiri (wirausaha) sehingga dapat menciptakan lapangan pekerjaan baru. 
Berdasarkan hasil observasi sementara dilapangan teryata minat wirausaha siswa SMK I,IV dan X dapat dikatagorikan cukup karena mereka sudah melakukan kegiatan usaha antara lain membuat kue lebaran, membuat toples hias untuk kue lebaran, membuat kerajinan taplak meja dengan dibatik, membatik baju dll.

Untuk dapat berwirausaha dengan baik agar dan dapat berhasil harus memiliki sikap percaya diri, berorientasikan tugasdan hasil, pengambilan resiko, kepemimpinan, keorisinilan, dan berorientasi ke masadepan.

Berdasarkan hasil observasi sementara di lapangan teryata sikap wirausaha siswa SMK I,IV dan X masih perlu dibina karena belum siap menghadapi tantangan dan beberapa permasalahan yang timbul, misalnya dalam menghadapi konsumen yang masih menemukan beberapa kesulitan.

Menurut Murphy and Peck (dalam Alma, 2013) menggambarkan delapan anak tangga untuk mencapai puncak karir. Delapan anak tangga ini dapat pula digunakan oleh seorang wirausaha dalam mengembangkan profesinya, yaitu: mau bekerja keras, bekerja sama dengan orang lain, penampilan yang baik, yakin, pandai membuat keputusan, mau menambah ilmu pengetahuan, ambisi untuk maju dan pandai berkomunikasi. Pandai berkomunikasi berarti pandai mengorganisasi buah pikiran ke dalam bentuk ucapan yang jelas, menggunakan tutur kata yang enak didengar, mampu menarik perhatian orang lain. Komunikasi baik, diikuti dengan perilaku jujur, konsisten dalam pembicaraan akan sangat membantu seseorang dalam mengembangkan karir masa depannya. Akhirnya dengan keterampilan berkomunikasi itu seseorang dapat mencapai puncak karir, meraih kursi empuk yang menjadi idaman setiap orang.

Berdasarkan hasil observasi sementara di lapangan teryata kemampuan berkomunikasi siswa SMK I,IV dan $\mathrm{X}$ dalam upaya melakukan kegiatan wirausaha cukup komunikatif terutama dalam menawarkan hasil produknya atau barang yang diperdagangkan sehingga calon pembeli tertarik untuk membeli.

Untuk menekan angka pengangguran, peran Sekolah Menengah Kejuruan (SMK) yang mempunyai peluang untuk mengembangkan kewirausahaan dalam mengubah sikap siswa dari mencari kerja menjadi pencipta lapangan kerja (wirausaha) dan mempunyai kemampuan berkomunikasi dengan baik maka di SMK khususnya jurusan Administrasi Perkantoran terdapat mata pelajaran produktif yang dapat diaplikasikan ke dalam dunia kerja.

Tujuan hasil belajar program keahlian administrasi perkantoran membekali peserta didik dengan keterampilan, pengetahuan dan sikap agar siswa memiliki kompetensi sesuai dengan standar kompetensi lulusan SMK di mana didalamnya terkandung unsur salah satunya untuk dapat berwirausaha sehingga dengan demikian diharapkan lulusan SMK memiliki minat untuk berwirausaha.

Hasil belajar siswa terhadap pelajaran produksi sudah cukup baik, walaupun ada juga siswa yang masih perlu pembinaan agardapat memperoleh hasil yang baik.

Dan sebagaimana diketahui bahwa di samping itu juga tujuan program keahlian administrasi perkantoranmembekali peserta didik dengan keterampilan, pengetahuan dan sikap agar siswa memiliki kompetensi di mana 
didalamnya terkandung unsur mampu berkomunikasi dalam hal ini mampu menerapkan dan mengembangkan kemampuan berkomunikasi baik lisan maupun tertulis dengan relasi dengan memperhatikan norma dan lingkungan masyarakat, mampu menerapkan dan mengembangkan pelayanan terhadap relasi sehingga diperoleh manfaat masing-masing pihak, mampu berkomunikasi lisan dan tulisan secara efektif dan santun, serta mampu menunjukkan keterampilan menyimak, membaca, menulis, dan berbicara dalam bahasa Indonesia dan Inggris, dengan demikian maka kemampuan berkomunikasi siswa sangat dibutuhkan untuk dapat berwirausaha dengan baik dan berhasil, sehingga diharapkan dengan mampu berkomunikasi dengan baik maka dapat memiliki minat untuk berwirausaha.

Orang-orang yang mempunyai nilai-nilai dan jiwa wirausaha yang ada pada dirinya, seperti mampu membaca peluang yang ada, menciptakan kegiatan usaha, dan memiliki keberanian dalam mengambil risiko dengan kemampuan yang dimilikinya. Selain itu seorang wirausaha memiliki beberapa ciri-ciri, fungsi dan peran sebagai seorang yang percaya diri, inisiatif, berprestasi, jiwa kepemimpinan dan berani mengambil risiko. Sehingga seorang wirausahawan memiliki suatu tantangan untuk memunculkan ide-ide baru dan jiwa yang tangguh agar menjadi seorang wirausawan yang berhasil, dengan demikian diharapkan dengan memiliki sikap wirausaha seperti yang diuraikan di atas maka dapat memiliki minat untuk berwirausaha.

Berdasarkan uraian diatas maka penulis tertarik untuk mengadakan penelitian dengan judul "Pengaruh Hasil Belajar Mata Pelajaran Produktif, Kemampuan Berkomunikiasi dan Sikap Wirausaha terhadap Minat Wirausaha Pada Siswa SMK Negeri Surabaya".

\section{METODE PENELITIAN}

Jenis penelitian yang digunakan dalam penelitian ini berdasarkan pendekatan adalah penelitian kuantitatif. Menurut Sugiyono (2011) metode penelitian kuantitatif merupakan metode penelitian yang berlandaskan pada filsafah positivism. Sedangkan jenis penelitian yang digunakan adalah penelitian tingkat eksplanasi (level of explanation). Menurut David Kline dalam Sugiyono (2008): “tingkat eksplanasi adalah tingkat penjelasan". Jadi penelitian ini adalah penelitian yang menjelaskan kedudukan variabel-variabel yang diteliti serta pengaruh antara satu variabel dengan variabel yang lain.

Berdasarkan tingkat eksplanasi, penelitian ini termasuk penelitian asosiatif. Dalam penelitian ini digunakan untuk mengetahui hasil belajar mata pelajaran produktif, kemampuan berkomunikasi dan sikap wirausaha terhadap minat wirausaha pada siswa kelas XI Administrasi Perkantoran SMK Negeri di surabaya. Yang digunakan adalah penelitian tingkat eksplanasi asosiatif bentuk kausal yang artinya jika siswa memiliki hasil belajar mata pelajaran produktif, kemampuan berkomunikasi dan sikap wirausaha yang baik maka akan menumbuhkan minat berwirausaha siswa SMK Negeri di Surabaya.

Pendekatan penelitian ini adalah pendekatan kuantitatif dengan menggambarkan regresi linier berganda, jadi ada variabel bebas dan variabel terikat. Variabel bebas dalam penelitian ini adalah hasil belajar mata pelajaran produktif, kemampuan berkomunikasi dan sikap wirausaha, sedangkan variabel 
terikat adalah minat berwirausaha $(\mathrm{Y})$. Ketiga variabel $\mathrm{X}_{1}, \mathrm{X}_{2}$, dan $\mathrm{X}_{3}$ akan dianalisis pengaruh masing-masing variabel bebas tersebut pada varibel terikat (Y). Analisis tersebut kemudian dilanjutkan dengan menganalisis ketiga variabel bebas tersebut secara bersama-sama.

Penelitian ini melihat pengaruh antar variabel bebas dan terikat sehingga dalam penelitian ini dirancang sebagaimana yang ditunjukkan oleh Gambar 1 sebagai berikut:

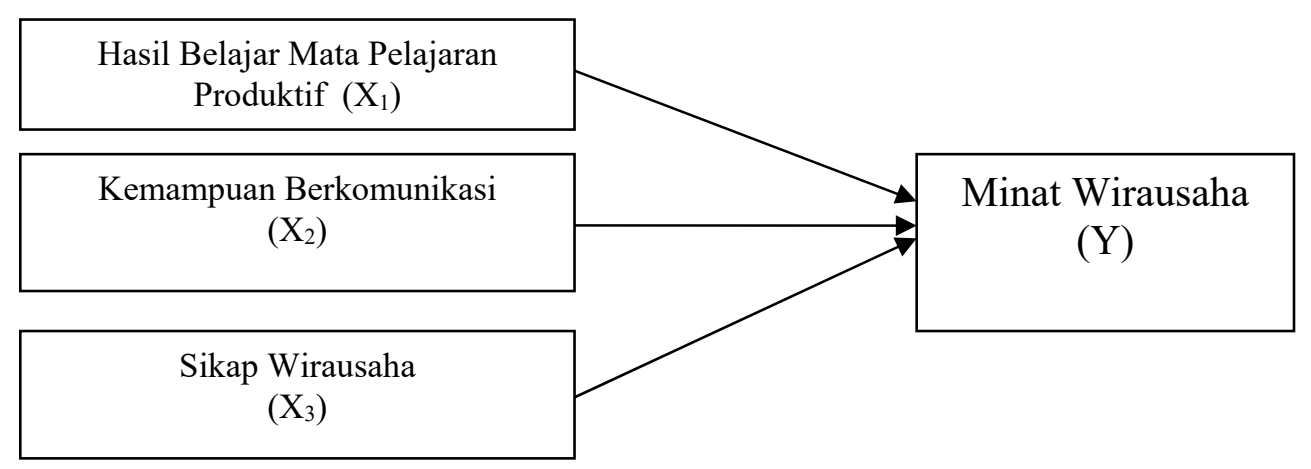

\section{Gambar 1. Pengaruh Antar Variabel Bebas dan Terikat}

1. Hasil belajar adalah kemampuan keterampilan, sikap dan keterampilan yang diperoleh siswa setelah ia menerima perlakuan yang diberikan oleh guru sehingga dapat mengkonstruksikan pengetahuan itu dalam kehidupan sehari-hari.

2. Mata Pelajaran Produktif pada kurikulum 2013 terdapat di peminatan administrasi perkantoran terutama pada kelompok C terdiri dari: C1 (Dasar Bidang Kejuruan), C2 (Dasar Kompetensi Kejuruan), C3 (Kompetensi Kejuruan) dan masing-masing memiliki kompetensi inti dan kompetensi dasar.

3. Kemampuan komunikasi adalah kemampuan menggunakan bahasa secara verbal (berupa kata-kata secara lisan maupun tertulis) dan nonverbal (isyarat, mimik wajah atau gerak tubuh) dengan baik agar tujuan dapat tercapai.

4. Sikap Wirausaha adalah bentuk tata kelakuan kewirausahaan yang berupa percaya diri, berorientasi pada tugas dan hasil, berani mengambil resiko, berjiwa kepemimpinan, berpikir ke arah hasil (manfaat), keorisinal.

5. Minat Berwirausaha adalah keinginan, ketertarikan, serta kesediaan individu melalui ide-ide yang dimiliki untuk bekerja keras atau berkemauan keras untuk berusaha memenuhi kebutuhan hidupnya, tanpa merasa takut dengan resiko yang akan terjadi, dapat menerima tantangan, percaya diri, dan inovatif serta mempunyai kemampuan dan keterampilan untuk memenuhi kebutuhan.

Menurut Sugiyono (2011) populasi adalah wilayah generalisasi yang terdiri atas: obyek/subyek yang mempunyai kualitas dan karakteristik tertentu yang ditetapkan oleh peneliti untuk dipelajari dan kemudian ditarik kesimpulannya. Jadi populasi bukan hanya orang, tetapi juga obyek dan bendabenda alam yang lain. 
Dalam penelitian ini, pupulasi yang diambil adalah semua siswa kelas XI Administrasi Perkantoran SMK Negeri di Surabaya. Kelas XI dipilih dengan pertimbangan bahwa siswa kelas XI merupakan siswa yang sudah cukup banyak menerima materi pelajaran produktif pada kurikulum 2013 yang telah diperolehnya sejak kelas X, selain itu pada kelas XI sudah mengikuti OJT (On The Job Training) di Du/DI sebagai pengaplikasian atau praktek kerja terhadap teori yang sudah diperolehnya selama di sekolah.

Menurut Sugiyono (2011) sampel adalah bagian dari jumlah dan karakteristik yang dimiliki oleh populasi tersebut. Metode penentuan sampel yang digunakan adalah probability sampling. Menurut Sugiyono (2011) Teknik probability sampling adalah teknik pengambilan sampel yang memberikan peluang yang sama bagi setiap unsur (anggota) populasi untuk dipilih menjadi anggota sampel. Alasan digunakan teknik, ini karena banyaknya sampel yang akan terpilih, sesuai dengan populasi yang teridentifikasi. Sedangkan jenis probability sampling yang digunakan adalah simple random sampling. Teknik pengambilan sampel ini dipilih oleh peneliti karena berasumsi anggota populasi adalah homogen (sejenis) yakni semuanya merupakan siswa kelas XI SMK Negeri di Surabaya dimana siswanya memiliki kualitas yang dianggap sama.

Teknik pengambilan sampel menggunakan pendapat Slovin (dalam Riduwan 2008) dapat menggunakan rumus:

$$
\begin{array}{llll} 
& \mathrm{n} & = & \mathrm{N} \\
& & & \mathrm{Nd}+1 \\
\text { Dimana: } & \mathrm{n} & = & \text { Jumlah sampel } \\
& \mathrm{N} & = & \text { Jumlah populasi } \\
& \mathrm{D} & = & \text { Presisi yang ditetapkan }(10 \%)
\end{array}
$$

Berdasarkan rumus diatas maka sampel untuk responden:

391

$$
\begin{aligned}
& \mathrm{n}=\frac{2}{391(0,1)^{2}+1} \\
& \mathrm{~N}=\frac{391}{4,91}=80
\end{aligned}
$$

Banyak sampel adalah 80 dari 391 populasi

Adapun rincian dari jumlah populasi tersebut sebagai berikut:

SMK NEGERI 1 SURABAYA $=150 / 391 X \quad 80=31$ Siswa

SMK NEGERI 4 SURABAYA $=127 / 391$ X $80=26$ Siswa

SMK NEGERI 10 SURABAYA $=114 / 391 \mathrm{X} 80=23$ Siswa

Jumlah

$=80$ Siswa

Jadi jumlah sampelnya $=23+26+31=80$

Penelitian ini dilakukan padasiswa kelas XI Administrasi Perkantoran di SMK Negeri Surabaya Tahun Ajaran 2014-2015. Adapun SMK Negeri di Surabaya yang memiliki jurusan Administrasi Perkantoran adalah:

1. SMK NEGERI 1 SURABAYA, Jalan SMEA No.4 Wonokromo Surabaya 
2. SMK NEGERI 4 SURABAYA, Jalan Kranggan 81-101 Surabaya

3. SMK NEGERI 10 SURABAYA, Jalan Keputih, Tegal, Sukolilo, Surabaya

Menurut Sugiyono (2011) kuesioner merupakan pengumpulan data yang dilakukan dengan cara memberi seperangkat pertanyaan atau pernyataan tertulis kepada responden untuk dijawabnya. Angket yang digunakan adalah angket langsung serta bersifat tertutup (kuesioner tipe pilihan) dan terbuka (kuesioner tipe pertanyaan), untuk angket tertutup menggunakan skala Likert (rating scale). Angket atau kuisioner tertutup digunakan untuk mengumpulkan data primer atas variabel kemampuan berkomunikasi, sikap wirausaha dan minat wirausaha sedangkan angket terbuka untuk tambahan variabel minat wirausaha. Sedangkan variabel hasil belajar mata pelajaran produktif menggunakan data nilai rapor siswa. Lebih lanjut, Sandjaya (2006) menjelaskan bahwa "pertanyaan pada angket ini menuntut jawaban responden dalam bentuk skala bertingkat, yang merupakan skala interval". Skor tertinggi yaitu 5 diberikan untuk pertanyaan paling positif, sedangkan skor terendah yaitu 1 untuk pertanyaan paling negatif. Teknik Likert dilaporkan Edwards dan Kenney (dalam Hajar 1999) "memiliki reliabilitas yang lebih tinggi dengan item yang lebih sedikit".

Tabel 1. Pola Penskoran Untuk Angket Kemampuan Berkomunikasi, Sikap Wirausaha dan Minat Wirausaha

\begin{tabular}{|c|c|}
\hline Alternatif Jawaban & Pernyataan \\
\hline Sangat Setuju & 4 \\
\hline Setuju & 3 \\
\hline Tidak Setuju & 2 \\
\hline Sangat Tidak Setuju & 1 \\
\hline
\end{tabular}

Riyanto (2007) menjelaskan bahwa "metode dokumentasi berarti cara mengumpulkan data dengan mencatat data-data yang sudah ada" Dokumen adalah bahan tertulis yang digunakan untuk keperluan penelitian karena dokumen merupakan sumber-sumber yang stabil, berguna sebagai bukti, dan sifatnya alamiah. Dokumen tersebut dapat berupa catatan, transkrip, buku, surat kabar, majalah, prasasti, notulen rapat, legger agenda dan sebagainya. Dalam penelitian ini, informasi dan data tertulis yang diambil adalah nilai dari penilaian performane (kinerja) nilai keaktifan siswa selama proses pembelajaran, penilaian hasil kerja berupa nilai hasil kegiatan yang dilakukan dan nilai hasil lembar kerja siswa setelah ia menerima perlakuan yang diberikan oleh guru pada masing-masing mata pelajaran produktif administrasi perkantoran pada siswa kelas XI Administrasi Perkantoran yang diperoleh dari mulai kelas X dan XI yang meliputi: Pengantar Ekonomi dan Bisnis, Pengantar Administrasi Perkantoran, Pengantar Akuntansi, Otomatisasi Perkantoran, Korespondensi, Kearsipan dan Simulasi Digital, Administrasi Kepegawaian, Administrasi Keuangan, Administrasi Sarana dan Prasaran dan Administrasi Humas dan Keprotokolan. serta kemampuan berkomunikasi, sikap wirausaha, dan minat wirausaha

Penelitian ini terdiri dari 3 variabel bebas dan 1 varibel terikat. Variabel bebas terdiri dari hasil belajar mata pelajaran produktif $\left(\mathrm{X}_{1}\right)$, kemampuan berkomunikasi $\left(\mathrm{X}_{2}\right)$ dan sikap wirausaha $\left(\mathrm{X}_{3}\right)$, dan satu variabel terikat yaitu 
minat wirausaha (Y). Variabel hasil belajar mata pelajaran produktif pengukurannya menggunakan nilai ulangan siswa kelas XI Administrasi Perkantoran SMK Negeri di surabaya. Sedangkan untuk variabel yang lainnya kemudian dibuat kisi-kisi penelitian sebagai berikut:

a. Variabel hasil belajar mata pelajaran produktif

Indikator variabel yang digunakan menurut Sudjana (1989) untuk mengukur kemampuan-kemampuan yang dimiliki siswa setelah menerima pengalaman belajarnya.

Mata Pelajaran Produktif pada kurikulum 2013 terdapat di peminatan administrasi perkantoran terutama pada kelompok C terdiri dari: C1 (Dasar Bidang Kejuruan), C2 (Dasar Kompetensi Kejuruan), C3 (Kompetensi Kejuruan) dan masing-masing memiliki kompetensi inti dan kompetensi dasar.

Adapun variabel hasil belajar terdapat pada mata pelajaran di kelas X dan XI jurusan administrasi perkantoran di dasar bidang kejuruan dan dasar kompetensi kejuruan, yaitu:

1. Pengantar Ekonomi dan Bisnis

2. Pengantar Administrasi Perkantoran

3. Pengantar Akuntansi

4. Otomatisasi Perkantoran

5. Korespondensi

6. Kearsipan

7. Simulasi Digital

8. Administrasi Kepegawaian

9. Administrasi Keuangan

10. Administrasi Sarana dan Prasarana

11. Administrasi Humas dan Keprotokolan

b. Variabel kemampuan berkomunikasi

Adapun indikator variabel yang digunakan untuk mengukur kemampuan berkomunikasi menurut Scott M.Cultip dan Allen H. Center meliputi:

1. Kepercayaan(Credibility)

2. Perhubungan(Context)

3. Kepuasan(Content)

4. Kejelasan(Clarity)

5. Kesinambungan dan konsisten (Continuity \& Consistency)

6. Kemampuan komunikan (Capability of audience

7. Channels of distribution (saluran pengiriman berita)

c. Variabel sikap wirausaha

Adapun indikator variabel yang digunakan untuk mengukur sikap wirausaha menurut Agus Wibowo (2011):

1. Percaya diri

2. Berorientasi pada tugas dan hasil

3. Berani mengambil resiko

4. Berjiwa kepemimpinan

5. Berpikir ke arah hasil (manfaat)

6. Keorisinal

d. Variabel minat wirausaha 
Adapun indikator variabel yang digunakan untuk mengukur minat wirausaha menurut Super dan Crites (dalam Sukardi, 1988) yaitu:

1. Pengungkapan/ucapan (expressed interest)

2. Tindakan/perbuatan (manifest interest)

3. Menjawab sejumlah pertanyaan (inventoried interest)

Uji validitas digunakan untuk mengukur sah atau valid tidaknya suatu kuesioner. Menurut Kuncoro (2009) suatu kuesioner dikatakan valid jika pernyataan dan kuesioner mampu untuk mengungkap sesuatu yang akan diukur oleh kuesioner tersebut. Dalam penelitian ini menggunakan analisis korelasi pearson dengan kriteria bahwa tingkat signifikan 5\% nilai $\mathrm{r}$ hitung $>\mathrm{r}$ tabel maka dapat disimpulkan bahwa butir instrumen tersebut valid.

Berdasarkan pada perhitungan tabel, dapat diketahui bahwa seluruh item pernyataan mengenai Hasil Belajar, dan Kemampuan Berkomunikasi maupun Minat Wirausaha yang berjumlah 47 item, mempunyai nilai $\mathrm{r}$ hitung lebih besar dari $r$ table dan sesuai dengan ketentuan yang telah ditetapkan, maka hal ini berarti bahwa semua pernyataan di atas dinyatakan valid dan dapat digunakan untuk penelitian.

Menurut Santosa dan Ashari (2005) Reliabilitas adalah ukuran yang menunjukkan konsistensi dari alat ukur dalam mengukur gejala yang sama di lain kesempatan. Pengujian reliabilitas dalam penelitian ini menggunakan bantuan komputer yang dilaksanakan oleh peneliti dengan menggunakan koefisien alpha Cronbach dengan ketentuan suatu konstruk atau variabel dikatakan reliabel jika memberikan nilai Cronbach Alpha $>0,60$,

Dari hasil uji terlihat nilai cronbach's alpha untuk seluruh variabel Setuju variabel bebas maupun variabel terikat menunjukkan nilai yang lebih besar dari 0,60 yang berarti butir-butir pernyataan dari seluruh variabel seluruhnya reliabel dan dapat digunakan dalam penelitian.

Setelah data dan ketiga variabel terkumpul, langkah selanjutnya adalah mengolah dan menganalisis data. Analisis data dilakukan bertujuan untuk menyederhanakan data kedalam bentuk yang lebih mudah untuk dibaca dan dipahami, dalam proses mi menggunakan statistik karena salah satu fungsi statistik adalah menyederhanakan data. Selain itu statistik juga membandingkan perolehan hasil yang terjadi secara kebetulan, sehingga memungkinkan peneliti untuk menguji apakah hubungan yang diamati memang benar terjadi karena adanya hubungan sistematis antara variabelvariabel yang diteliti atau karena kebetulan.

Dalam penelitian ini teknik analisis data yang yang digunakan adalah analisis regresi linier berganda dengan bantuan program komputer SPSS. Analisis regresi ini lebih sesuai dengan kenyataan di lapangan bahwa suatu variãbel terikat tidak hanya dapat dijelaskan oleh satu variabel bebas saja tetapi perlu dijelaskan oleh beberapa variabel terikat.

Menurut Hasan (2002) analisis regresi berganda adalah analisis tentang hubungan antara satu variabel terikat $(\mathrm{Y})$ dengan dua atau lebih variabel bebas (X). Analisis regresi linier berganda digunakan untuk menjawab rumusan masalah penelitian pengaruh hasil belajar mata pelajaran produktif, kemampuan berkomunikasi dan sikap wirausaha terhadap minat wirausaha. Adapun rumus regresi linier berganda yang digunakan adalah: 


$$
\mathbf{Y}=\mathbf{b}_{0}+\mathbf{b}_{1} \mathbf{X}_{1}+\mathbf{b}_{2} \mathbf{X}_{2}+\mathbf{b}_{3} \mathbf{X}_{3}
$$

Dimana:

$\begin{array}{ll}\mathrm{Y} & =\text { Minat Berwirausaha } \\ \mathrm{b}_{0} & =\text { Konstanta } \\ \mathrm{b}_{1}, \mathrm{~b}_{2} \text { dan } \mathrm{b}_{3} & =\text { Koefisien korelasi untuk masing-masing variabel } \\ \mathrm{X}_{1} & =\text { Variabel Hasil Belajar Mata Pelajaran Produktif } \\ \mathrm{X}_{2} & =\text { Variabel Kemampuan Berkomunikasi } \\ \mathrm{X}_{3} & =\text { Variabel Sikap Wirausaha }\end{array}$

Dalam melakukan analisis regresi sebagai prasyarat uji statistik maka dalam penelitian ini menggunakan uji asumsi.

Pengujian normalitas dalam asumsi klasik regresi adalah normalitas residual regresi. Uji normalitas dalam penelitian ini menggunakan uji normalitas Kolmogorov-Smirnov. Untuk mengetahui asumsi kenormalan tercapai atau tidak, dapat dilihat tingkat signifikannya dari Unstandardized Residual yang dihasilkan, bila nilai signifikansinya $>$ dari 0,05 maka data berdistribusi normal.

Model regresi dalam penelitian ini dapat memenuhi syarat apabila tidak terjadi multikolinieritas atau adanya korelasi di antara variabel bebas. Pengujian Multikolinieritas ini dapat dilihat dan nilai variance inflation factor (VIF). Antara variabel bebas dikatakan multikolinieritas apabila toleransinya < 0,1 dan VIF $>10$.

Uji Heteroskedastisitas bertujuan untuk menguji apakah model regresi terjadi ketidaksarnaan varian dari residual suatu pengamatan ke pengamatan yang lain. Model regresi yang baik adalah yang homoskedastisitas atau tidak terjadi heteroskedastisitas denagn melihat grafik plot antara nilai prediksi $n$ variabel terikat ZPRED dengan residual SRESID. Deteksi ada tidaknya heteroskedastisitas dapat dilakukan dengan melihat ada tidaknya pola tertentu pada grafik scatterplot antara SRESID dan ZPRED dimana sumbu Y adalah sumbu yang telah diprediksi dan sumbu $X$ adalah residual yang di studentized. Jika ada pola tertentu seperti titik-titik yang membentuk pola tertentu yang teratur (bergelombang, menyebar, dan menyempit) maka dikatakan telah terjadi heteroskedastisitas, dan jika tidak ada pola yang jelas serta titik-titik menyebar dlatas dan dibawah angka 0 pada sumbu $Y$ maka tidak terjadi heteroskedastisitas.

Uji linieritas merupakan prosedur yang digunakan untuk mengetahui status linier atau tidaknya suatu distribusi data penelitian, atau dikatakan apakah antar dependent variable dan independent variable tersebut linier. Hasil yang diperoleh pada uji linieritas menentukan teknik Anareg (Analisis Regresi) yang akan digunakan. Bila dari hasil uji linieritas didapatkan kesimpulan bahwa distribusi pada penelitian dikategorikan linier, data penelitian diselesaikan dengan teknik Anareg linier. Bila ternyata tidak linier maka distribusi data penelitian harus dianalisis Anareg non linier. Teknik yang digunakan untuk menguji, menggunakan model Curve Fit dan tabel Anova. Bila p linieritas $<0,05$ dapat dikatakan linier, berarti variabel bebas termasuk layak sebagai salah satu predictor variabel terikat, demikian juga sebaliknya. 
Pengujian hipotesis dalam penelitian ini meliputi uji parsial dan uji simultan. Pengujian secara parsial digunakan untuk menguji signifikansi koefisien regresi maupun korelasi parsial atau hubungan masing-masing variabel bebas dengan variabel terikat $(Y)$. Dasar pengambilan keputusan berdasarkan angka probabilitas. Jika angka probabilitas hasil analisis $<0,05$ maka Ho ditolak dan Ha diterima. Apabila Ha diterima menunjukkan ada pengaruh yang signifikan hasil belajar mata pelajaran produktif, kemampuan berkomunikasi dan sikap wirausaha pada minat wirausaha secara parsial.

Pengujian secara simultan digunakan untuk menguji signifikansi korelasi ganda adalah analisis tentang hubungan antara dua variabel atau lebih variabel bebas (independent variabel) dengan satu variabel terikat (dependent variabel). Dalam penelitian ini, analisis korelasi untuk mengetahui hubungan antara hasil belajar mata pelajaran produktif, kemampuan berkomunikasi dan sikap wirausaha pada minat wirausaha. Analisis regresi berganda bertujuan untuk meramalkan nilai pengaruh dua atau lebih variabel bebas pada satu variabel terikat. Dasar pengambilan keputusan berdasarkan angka probabilitas. Jika probabilitas hasil analisis $<0,05$ maka Ho ditolak dan Ha diterima yang berarti ada pengaruh secara simultan hasil belajar mata pelajaran produktif, kemampuan berkomunikasi dan sikap wirausaha pada minat wirausaha.

Untuk mengukur derajat hubungan antara 4 variabel yang digunakan dalam penelitian ini yaltu hasil belajar mata pelajaran produktif, kemampuan berkomunikasi, sikap wirausaha dan minat wirausaha dilakukan uji koefisien determinasi. Perhitungan koefisien determinasi secara simultan yang dilakukan dengan SPSS dapat dilihat dan besarnya $R$ square, sedangkan hasil koefisien determinasi secara parsial dapat dilihat dengan mengkuadratkan besarnya nilai correlations partial. Dalam menghitung besarnya koefisien determinasi dengan menggunakan SPSS dapat dilakukan serentak dengan pengujian hipotesis dengan langkah-langkah yang sama

\section{HASIL PENELITIAN DAN PEMBAHASAN}

Penelitian ini mengambil sampel siswa SMK Negeri 1, 4 dan 10 Jurusan Administrasi Perkantoran di Surabaya. Adapun jumlah responden adalah 80 siswa dari 391 siswa yang dianalisis dalam penelitian ini dan diklasifikasikan berdasarkan data responden yang menjadi sampel dalam penelitian ini yang kemudian diklasifikasikan berdasarkan data responden yang meliputi karakteristik jenis kelamin, kelas, dan pekerjaan orang tua siswa SMK Negeri Surabaya.

Analisis data secara deskriptif ini menguraikan hasil analisis terhadap siswa SMK Negeri Surabaya dengan menguraikan tanggapan dari 80 siswa SMK Negeri Surabaya berdasarkan data dari kuesioner dan dokumentasi yang terkumpul.

Dalam pembahasan penelitian ini akan dijelaskan tentang rata-rata tanggapan siswa SMK Negeri Surabaya terhadap indikator-indikator variabel secara keseluruhan serta jumlah siswa SMK Negeri Surabaya yang memberikan jawaban terhadap masing-masing indikator variabel. 
Untuk mengetahui hasil rata-rata tanggapan siswa SMK Negeri Surabaya digunakan interval class yang bertujuan untuk menghitung nilai atau skor jawaban yang diisi oleh siswa SMK Negeri Surabaya.

Interval kelas $=\frac{\text { Nilai Tertinggi }- \text { Nilai Terendah }}{\text { Jumlah kelas }}=\frac{4-1}{4}=0,75$

Tabel 2. Kelas Interval

\begin{tabular}{|c|c|c|}
\hline No. & Interval Rata-rata & Kategori \\
\hline \hline 1 & $1,00 \leq \mathrm{x}<1,75$ & Sangat Tidak Setuju \\
2 & $1,75 \leq \mathrm{x}<2,50$ & Tidak Setuju \\
3 & $2,50 \leq \mathrm{x}<3,25$ & Setuju \\
4 & $3,25 \leq \mathrm{x}<4,00$ & Sangat Setuju \\
\hline
\end{tabular}

Sumber: Simamora (2004)

Dalam pembahasan penelitian ini akan dijelaskan tentang rata-rata tanggapan siswa SMK Negeri Surabaya terhadap indikator-indikator variabel secara keseluruhan serta jumlah siswa SMK Negeri Surabaya yang memberikan jawaban terhadap masing-masing indikator variabel.

Untuk lebih jelasnya, maka berikut ini merupakan hasil dari tanggapan siswa SMK Negeri Surabaya dari masing - masing variabel, yaitu sebagai berikut:

- yang mendapat nilai dibawah 2,7 sebanyak 0 responden dengan persentase $0 \%$

- yang mendapatkan nilai antara 2,7 - 3,0 sebanyak 0 responden dengan persentase $0 \%$ yang mendapatkan nilai 3,0 - 3,2 sebanyak 0.responden dengan persentase $0 \%$

- yang mendapatkan nilai 3,3 - 3,5 sebanyak 76.responden dengan persentase $95 . \%$

- yang mendapatkan nilai 3,5 - 3,7sebanyak 3..responden dengan persentase $3,8 \%$

- yang mendapatkan nilai 3,8 - 4,0 sebanyak 1.responden dengan persentase $1,2 \%$

Adapun hasil belajar diambil dari penilaian performane (kinerja) nilai keaktifan siswa selama proses pembelajaran, penilaian hasil kerja berupa nilai hasil kegiatan yang dilakukan dan nilai hasil lembar kerja siswa setelah ia menerima perlakuan yang diberikan oleh guru pada masing-masing mata pelajaran produktif administrasi perkantoran pada siswa kelas XI Administrasi Perkantoran yang diperoleh dari mulai kelas $\mathrm{X}$ dan XI yang meliputi: Pengantar Ekonomi dan Bisnis, Pengantar Administrasi Perkantoran, Pengantar Akuntansi, Otomatisasi Perkantoran, Korespondensi, Kearsipan dan Simulasi Digital, Administrasi Kepegawaian, Administrasi Keuangan, Administrasi Sarana dan Prasaran dan Administrasi Humas dan Keprotokolan.

Berdasarkan hasil penelitian diketahui bahwa nilai hasil siswa SMK Negeri Surabaya akan variabel nilai hasil belajar mata pelajaran produktif $\left(\mathrm{X}_{1}\right)$ nilai hasil belajar mata pelajaran pengantar administrasi perkantoran di kelas 
XI pada semester 4 memperoleh nilai rata-rata tertinggi yaitu 3.49 kategori baik $(\mathrm{B}+)$.Hal ini menunjukkan bahwa mata pelajaran pengantar administrasi perkantoran sudah dikuasai oleh siswa sesuai dengan jurusannya yaitu administrasi perkantoran. Hasil belajar siswa SMK Negeri Surabaya akan variabel Hasil Belajar $\left(\mathrm{X}_{1}\right)$ sebagian besar tergolong kategori baik $(\mathrm{B}+)$ karena mean 3,4524 .

Adapun tanggapan siswa SMK Negeri Surabaya mengenai Kemampuan Berkomunikasi. Variabel Kemampuan Berkomunikasi diukur dengan 7 pernyataan indikator yaitu Kepercayaan, Perhubungan, Kepuasan, Kejelasan, Kesinambungan dan konsisten, Kemampuan komunikan, dan Saluran pengiriman berita yang dikembangkan menjadi 15. Dan hasil tanggapan siswa SMK Negeri Surabaya akan variabel Kemampuan Berkomunikasi $\left(\mathrm{X}_{2}\right)$ sebagian besar menyatakan pernyataan berikut "Saya selalu saling mempercayai lawan bicara saya", dengan memiliki nilai rata-rata tertinggi sebesar 3.54, pernyataan ini terdapat pada indikator "kepercayaan". Hal ini menunjukkan bahwa siswa SMK Negeri Surabaya sangat sesuai dengan kemampuan berkomunikasi yang mengutamakan kepentingan bersama antara organisasi dan siswa. Sedangkan secara keseluruhan nilai rata-rata tanggapan siswa SMK Negeri Surabaya tentang seluruh variabel kemampuan berkomunikasi tersebut sebesar 3.32.Dalam interval kelas termasuk dalam kategori 3,25 $\leq \mathrm{x}<4,00$, yang menunjukkan siswa SMK Negeri Surabaya memberi nilai Sangat Setuju atas pernyataan tentang semua variabel Kemampuan Berkomunikasi.

Adapun variabel sikap wirausaha diukur dengan 6 pernyataan indikator yaitu Percaya diri, Berorientasi pada tugas dan hasil, Berani mengambil resiko, Berjiwa kepemimpinan, Berpikir kearah hasil (manfaat), Keorisinal yang kemudian dikembangan menjadi 20 pernyataan

Berdasarkan penelitian hasil tanggapan siswa SMK Negeri Surabaya akan variabel Sikap Wirausaha $\left(\mathrm{X}_{3}\right)$ sebagian besar menyatakan pernyataan berikut "Saya selalu memiliki inisiatif dalam berwirausaha", dengan memiliki nilai rata-rata tertinggi sebesar 3.56, pernyataan ini terdapat pada indikator "berorientasi pada tugas dan hasil". Hal ini menunjukkan bahwa siswa SMK Negeri Surabaya sangat sesuai dengan sikap wirausaha dengan memenuhi kebutuhan akan prestasi dan orientasi pekerjaan berupa laba, tekun dan tabah, tekad kerja keras serta berinisiatif. Sedangkan secara keseluruhan nilai rata-rata tanggapan siswa SMK Negeri Surabaya tentang seluruh variabel Sikap Wirausaha tersebut sebesar 3.38.Dalam interval kelas termasuk dalam kategori $3,25 \leq \mathrm{x}<4,00$, yang menunjukkan siswa SMK Negeri Surabaya memberi nilai Sangat Setuju atas pernyataan tentang semua variabel Sikap Wirausaha.

Minat Wirausaha diukur melalui 3 pernyataan indikator yaitu Pengungkapan, tindakan dan menjawab sejumlah pertanyaan yang dikembangankan menjadi 12. Adapun hasil tanggapan akan variabel Minat Wirausaha (Y) sebagian besar siswa SMK Negeri Surabaya menyatakan Sangat Setuju pada pernyataan "Saya senang membaca artikel tentang cerita wirausahawan sukses di majalah dan Koran", dengan memiliki nilai rata-rata tertinggi sebesar 3.58, , pernyataan ini terdapat pada indikator "tindakan". Hal ini menunjukkan bahwa sebagian besar siswa SMK Negeri Surabaya memiliki kepribadian yang sangat baik dan menyadari akan penting tingkat produktivitas 
perusahaan. Sedangkan secara keseluruhan nilai rata-rata tanggapan siswa SMK Negeri Surabaya tentang seluruh variabel Minat Wirausaha tersebut sebesar 3.39. Dalam interval kelas termasuk dalam $3,40 \leq \mathrm{x}<4,20$, yang menunjukkan siswa SMK Negeri Surabaya memberi nilai Sangat Setuju atas pernyataan tentang semua variabel Minat Wirausaha.

Tabel 3. Hasil Uji Normalitas

\begin{tabular}{|l|r|}
\hline & Unstandardized Residual \\
\hline Kolmogorov-Smirnov Z & 0.980 \\
\hline Asymp. Sig. (2-tailed) & 0.292 \\
\hline
\end{tabular}

Berdasarkan pada tabel di atas dapat diketahui bahwa besarnya nilai Asymp sig (2-tailed) sebesar $0.292>0,05$, sehingga dapat disimpulkan bahwa residual berdistribusi normal dan asumsi regresi terpenuhi.

Tabel 4. Hasil Uji Multikolinieritas

\begin{tabular}{|l|c|c|c|}
\hline \multicolumn{1}{|c|}{ Variabel } & Tolerance & VIF & Keterangan \\
\hline Hasil Belajar $\left(\mathrm{X}_{1}\right)$ & 0.979 & 1.022 & Bebas Multikolinieritas \\
\hline $\begin{array}{l}\text { Kemampuan } \\
\text { Berkomunikasi }\left(\mathrm{X}_{2}\right)\end{array}$ & 0.484 & 2.067 & Bebas Multikolinieritas \\
\hline Sikap Wirausaha $\left(\mathrm{X}_{3}\right)$ & 0.477 & 2.098 & Bebas Multikolinieritas \\
\hline
\end{tabular}

Berdasarkan pada tabel di atas dapat diketahui bahwa nilai toleransi dari masing-masing variabel diatas 0.1 dan nilai VIF di bawah 10. Hal tersebut menunjukkan bahwa tidak terjadi gejala multikolinearitas, sehingga asumsi regresi terpenuhi.

Pengujian heteroskedaktisitas dalam penelitian ini dengan melihat pola titik - titik pada scatterplot regresi regresi linear berganda.

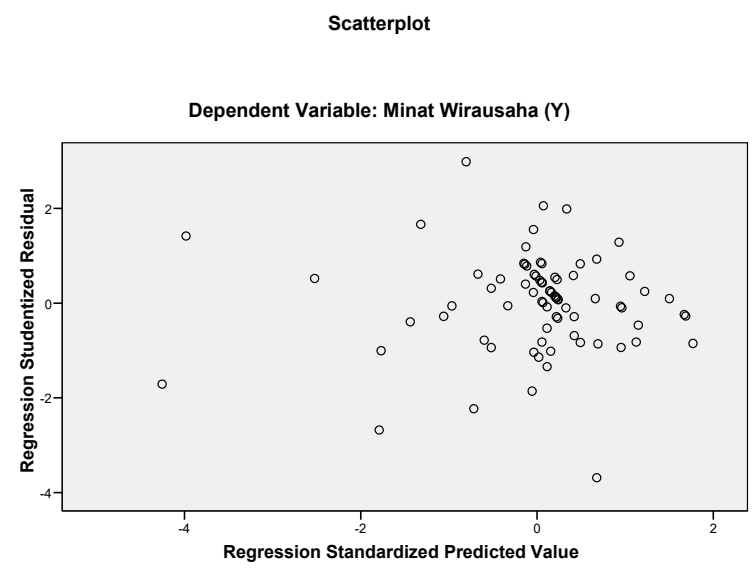

Gambar 2. Grafik Pengujian Heteroskedaktisitas 
Berdasarkan grafik scatter plot diatas, diketahui titik menyebar secara acak baik di atas maupun di bawah angka nol pada sumbu Y. Jadi, tidak ada pola yang jelas, serta titik-titik menyebar di atas dan di bawah angka 0 pada sumbu Y, maka dapat dikatakan bahwa tidak terjadi Heteroskedastistas.

Hasil pengolahan data variabel dapat dijelaskan bahwa nilai signifikansi pada liniearity di bawah 0.05, maka dapat disimpulkan antara variabel Hasil Belajar, dengan Minat Wirausaha terdapat hubungan non linear, dan Kemampuan Komunikasi dengan Minat Wirausaha terdapat hubungan linear yang signifikan, serta Sikap Wirausaha, dengan Minat Wirausaha terdapat hubungan linear yang signifikan.

Tabel 5. Uji Autokorelasi

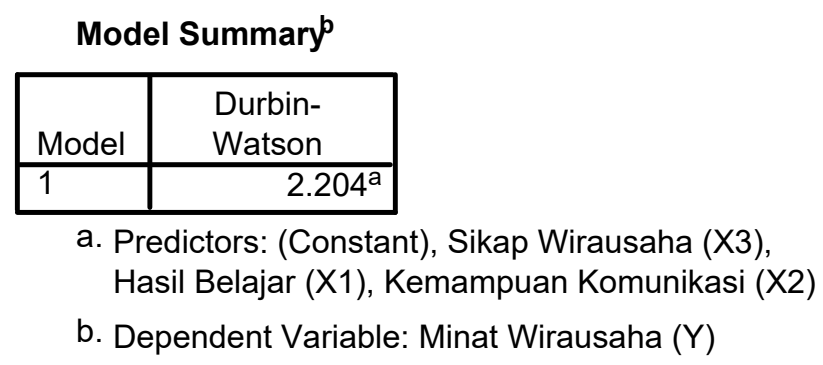

Dari penelitian ini menunjukan bahwa nilai Durbin Watson adalah 2.204, berarti terletak nilai Durbin Watson tersebut terletak pada range 1,55 - 2,46 maka dapat disimpulkan tidak ada autokorelasi. Jadi pengujian autokorelasi dalam penelitian ini telah terpenuhi.

Analisis regresi linear berganda ini bertujuan untuk meneliti bagaimana masing-masing variabel bebas Hasil Belajar $\left(\mathrm{X}_{1}\right)$, Kemampuan Berkomunikasi $\left(\mathrm{X}_{2}\right)$, dan Sikap Wirausaha $(\mathrm{X} 3)$ terhadap variabel terikat Minat Wirausaha $(\mathrm{Y})$ pada penelitian ini.

Dari perhitungan penelitian persamaan regresi yang didapat adalah:

$$
Y=0.345-0.164 X_{1}+0.534 X_{2}+0.544 X_{3}+e
$$

Dari persamaan regresi di atas dapat diuraikan sebagai berikut:

1. Nilai Minat Wirausaha (Y) sebesar sebesar 0.345 ketika Hasil Belajar (X), Kemampuan Berkomunikasi $\left(\mathrm{X}_{2}\right)$, dan Sikap Wirausaha $\left(\mathrm{X}_{3}\right)$ bernilai sama dengan nol.

2. Nilai koefisien Hasil Belajar $\left(\mathrm{X}_{1}\right)$ sebesar -0.164 menunjukkan bahwa jika variabel Hasil Belajar $\left(\mathrm{X}_{1}\right)$ turun satu satuan, maka akan mengakibatkan penurunan Minat Wirausaha sebesar -0.164 dan diasumsikan untuk variabel Kemampuan Berkomunikasi konstan dan Sikap Wirausaha konstan Nilai koefisien Kemampuan Berkomunikasi $\left(\mathrm{X}_{2}\right)$ sebesar 0.534 menunjukkan bahwa jika variabel Kemampuan Berkomunikasi $\left(\mathrm{X}_{2}\right)$ naik satu satuan, maka akan mengakibatkan peningkatan Minat Wirausaha sebesar 0.534 dengan asumsi variabel Hasil Belajar dan Kemampuan Berkomunikasi konstan

3. Nilai koefisien Sikap Wirausaha $\left(\mathrm{X}_{3}\right)$ sebesar 0.544 menunjukkan bahwa jika variabel Sikap Wirausaha $\left(\mathrm{X}_{3}\right)$ naik satu satuan, maka akan mengakibatkan peningkatan Minat Wirausaha sebesar 0.544 dengan asumsi variabel Sikap Wirausaha dan konstan 
Koefisien korelasi $(\mathrm{R})$ adalah tingkat keeratan hubungan antara variabel bebas dengan variabel terikat yang bernilai diantara -1 sampai dengan 1 .

Dari perhitungan hasil penelitian diketahui bahwa nilai koefisien korelasi (R) sebesar 0.893 Nilai tersebut menunjukkan bahwa hubungan variabel Hasil Belajar $\left(\mathrm{X}_{1}\right)$, dan Kemampuan Berkomunikasi $\left(\mathrm{X}_{2}\right)$, dan Sikap Wirausaha $\left(\mathrm{X}_{3}\right)$ dengan variabel Minat Wirausaha (Y) adalah cukup erat, karena nilai 0.893 sudah mendekati 1 (Sugiyono 2008).

Nilai koefisien determinasi (R square) sebesar 0.797. Hal ini menunjukan bahwa 79.7\% variasi dalam variabel Minat Wirausaha dapat dijelaskan oleh variabel Motivasi $\left(\mathrm{X}_{1}\right)$, dan Kemampuan Berkomunikasi $\left(\mathrm{X}_{2}\right)$, Sikap Wirausaha $\left(\mathrm{X}_{3}\right)$ Sedangkan sisanya $20.3 \%$ dijelaskan variabel lain yang tidak termasuk dalam penelitian ini.

Uji F dilakukan untuk mengetahui Setuju variabel independen secara serentak terhadap variabel dependen, apakah Setujunya signifikan atau tidak (Sugiyono, 2008).

a. Adapun perumusan hipotesis pada uji $\mathrm{F}$ adalah sebagai berikut:

$H_{0}: \beta_{1}=\beta_{2}=\beta_{3}=0$ artinya variabel bebas secara simultan atau secara bersama-sama tidak berpengaruh secara signifikan terhadap variabel terikat.

$\mathrm{H}_{1}: \beta_{1} \neq \beta_{2} \neq \beta_{3} \neq 0 \quad$ artinya variabel bebas secara simultan atau secara bersama-sama berpengaruh secara signifikan terhadap variabel terikat.

b. Hasil pengujiannya adalah sebagai berikut:

Tabel 3. Uji Simultan (Uji F)

\begin{tabular}{|l|c|c|c|c|c|}
\hline \multicolumn{1}{|c|}{ Model } & Sum of Squares & Df & $\begin{array}{c}\text { Mean } \\
\text { Square }\end{array}$ & F & Sig. \\
\hline Regression & 12.183 & 3 & 4.061 & & \multirow{2}{*}{0.000} \\
\hline Residual & 3.098 & 76 & 0.041 & \multirow{2}{*}{99.640} & \\
\hline Total & 15.281 & 79 & - & & \\
\hline
\end{tabular}

c. Penentuan Ftabel

$\mathrm{F}$ tabel $=\mathrm{F}_{\alpha}(\mathrm{df}$ regresi, $\mathrm{df}$ residual $)=\mathrm{F}_{\alpha}(\mathrm{k}, \mathrm{n}-\mathrm{k}-1)$

$\mathrm{F}_{\text {tabel }}=\mathrm{F}_{0.05}(3,76)=2.72$

d. Daerah kritis atau daerah penolakan

Bila $\mathrm{F}$ hitung $\geq \mathrm{F}$ tabel maka $\mathrm{H}_{0}$ ditolak

Bila $\mathrm{F}$ hitung $<\mathrm{F}$ tabel maka $\mathrm{H}_{0}$ diterima

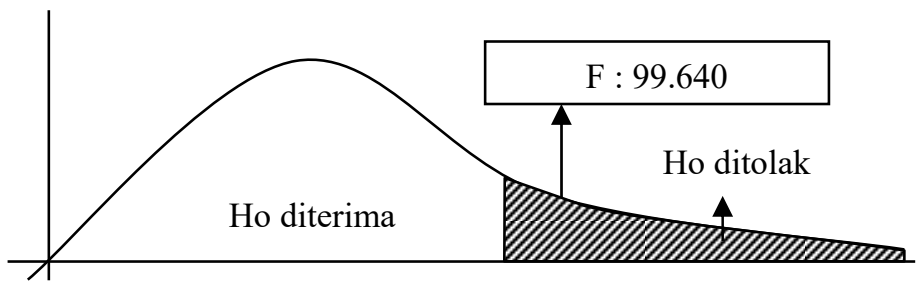

Gambar 3. Grafik Uji F

e. Simpulan

Dari hasil output diatas diperoleh nilai $F_{\text {hitung }} 99.640$ atau lebih besar dari $F_{\text {tabel }}$ 2.72, maka $\mathrm{H}_{0}$ ditolak, sehingga dapat disimpulkan bahwa variabel bebas 
yang terdiri dari Hasil Belajar, Kemampuan Berkomunikasi, Sikap Wirausaha memiliki pengaruh secara simultan atau secara bersama-sama terhadap variabel terikat yaitu Minat Wirausaha.

Uji $t$ dilakukan untuk mengetahui pengaruh variabel independen secara parsial terhadap variabel dependen, apakah pengaruhnya signifikan atau tidak (Sugiyono, 2007).

a. Adapun perumusan hipotesis dalam pengujian ini adalah sebagai berikut:

$\mathrm{H}_{0}$ : artinya, variabel bebas tidak mempunyai pengaruh yang signifikan secara parsial terhadap variabel terikat.

$\mathrm{H}_{1}$ : artinya, variabel bebas mempunyai pengaruh yang signifikan secara parsial terhadap variabel terikat.

b. $\quad \alpha=0,05 / 2=0.025$ dengan $\mathrm{df}(\mathrm{n}-\mathrm{k}-1)=76$ dimana tabel $=1.99167$

c. Kriteria pengujian yang digunakan adalah jika thitung lebih besar dari tabel maka $\mathrm{H}_{0}$ ditolak pada tingkat signifikansi $5 \%$.

d. Daerah kritis

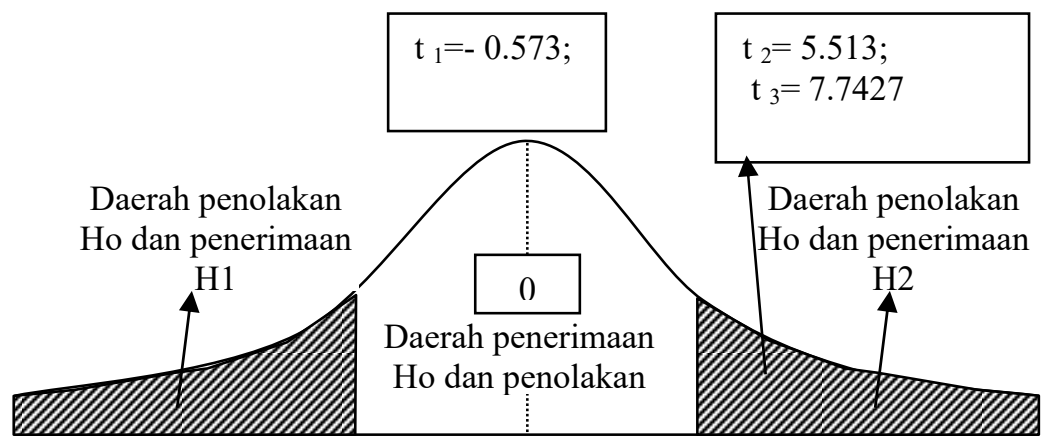

Gambar 4. Grafik Uji t

Hasil pengujian uji $t$ dari masing-masing variabel bebas Hasil Belajar dan Kemampuan Berkomunikasi adalah sebagai berikut:

a. Uji Parsial Setuju Variabel Hasil Belajar $\left(\mathrm{X}_{1}\right)$ Terhadap Minat Wirausaha Berdasarkan tabel 4.16diatas diketahui besarnya nilai thitung variabel bebas Hasil Belajar $\left(\mathrm{X}_{1}\right)$ adalah -0.573 atau lebih kecil dari tabel 1.99167 . Hal ini menunjukan bahwa $\mathrm{H}_{0}$ diterima dan $\mathrm{H}_{1}$ ditolak sehingga variabel bebas Hasil Belajar $\left(\mathrm{X}_{1}\right)$ tidak memiliki pengaruh signifikan secara parsial terhadap Minat Wirausaha (Y).

b. Uji Parsial Setuju Variabel Kemampuan Berkomunikasi $\left(\mathrm{X}_{2}\right)$ Terhadap Minat Wirausaha

Berdasarkan tabel 4.16diatas diketahui besarnya nilai thitung variabel bebas Kemampuan Berkomunikasi $\left(\mathrm{X}_{2}\right)$ adalah 5.513 atau lebih besar dari tabel 1.99167. Hal ini menunjukan bahwa $\mathrm{H}_{0}$ ditolak dan $\mathrm{H}_{1}$ diterima sehingga variabel bebas Kemampuan Berkomunikasi $\left(\mathrm{X}_{2}\right)$ memiliki pengaruh signifikan secara parsial terhadap Minat Wirausaha.

c. Uji Parsial Setuju Variabel Sikap Wirausaha $\left(\mathrm{X}_{3}\right)$ Terhadap Minat Wirausaha

Berdasarkan tabel 4.16diatas diketahui besarnya nilai thitung variabel bebas Sikap Wirausaha $\left(\mathrm{X}_{3}\right)$ adalah 7.427 atau lebih besar dari tabel 1.99167. Hal ini menunjukan bahwa $\mathrm{H}_{0}$ ditolak dan $\mathrm{H}_{1}$ diterima sehingga variabel bebas 
Sikap Wirausaha $\left(\mathrm{X}_{2}\right)$ memiliki pengaruh signifikan secara parsial terhadap Minat Wirausaha.

Nilai korelasi parsial (r) menunjukkan berapa erat hubungan antara variabel bebas yang meliputi variabel Hasil Belajar $\left(\mathrm{X}_{1}\right)$, dan Kemampuan Berkomunikasi $\left(\mathrm{X}_{2}\right)$, secara parsial terhadap variabel terikat Minat Wirausaha (Y).

Berdasarkan data penelitaian yang didapat dilihat bahwa nilai koefisien determinasi $\left(\mathrm{r}^{2}\right)$ terbesar adalah untuk variabel Sikap Wirausaha $\left(\mathrm{X}_{3}\right)$ sebesar 0.420 , artinya secara parsial variabel Sikap Wirausaha $\left(\mathrm{X}_{3}\right)$ memberikan pengaruh yang dominan terhadap Minat Wirausaha dengan nilai prosentase hubungan sebesar $42.0 \%$.

\section{Pengaruh Hasil Belajar Mata Pelajaran Produktif Terhadap Minat Wirausaha}

Dari hasil penelitian didapatkan bahwa variabel Hasil Belajar Mata Pelajaran Produktif tidak mempunyai pengaruh signifikan positif secara parsial terhadap Minat Wirausaha SMK Negeri Surabaya, hal ini dapat diketahui dari nilai thitung sebesar -0.573 lebih kecil dari tabel sebesar 1.99167 maka $\mathrm{H}_{0}$ diterima pada tingkat signifikansi 5\% sehingga kesimpulannya adalah variabel Hasil Belajar $\left(\mathrm{X}_{1}\right)$ tidak mempunyai pengaruh signifikan positif terhadap minat wirausaha di SMK Negeri Surabaya. Hal ini menunjukkan bahwa semakin tinggi hasil belajar yang dimiliki oleh siswa maka belum tentu meningkatkan minat irausaha siswa SMK Negeri. Jadi hipotesis penelitian yang pertama "Diduga hasil belajar mata pelajaran produktif berpengaruh terhadap minat wirausaha pada siswa SMK Negeri Surabaya" dinyatakan ditolak.

Hasil dalam penelitian ini tidak sesuai penelitian yang dilakukan oleh Komsi Koranti (2013) yang membuktikan lingkungan eksternal yang diukur dari hasil belajar siswa berpengaruh terhadap minat wirausaha. Sehingga dapat dikatakan tidak terealisasinya dengan baik tujuan program keahlian administrasi perkantoran membekali peserta didik dengan keterampilan, pengetahuan dan sikap agar siswa memiliki kompetensi sesuai dengan standar kompetensi lulusan SMK di mana didalamnya terkandung unsur salah satunya untuk dapat berwirausaha sehingga dengan demikian diharapkan lulusan SMK memiliki minat untuk berwirausaha.

Sebagaimana diketahui bahwa tujuan Kurikulum 2013 adalah untuk mempersiapkan manusia Indonesia agar memiliki kemampuan hidup sebagai pribadi dan warga negara yang beriman, produktif, kreatif, inovatif, dan afektif serta mampu berkontribusi pada kehidupan bermasyarakat, berbangsa, bernegara, dan peradaban dunia dan Menurut Peraturan Pemerintah No.66 Tahun 2010, Sekolah Menengah Kejuruan (SMK) merupakan salah satu bentuk pendidikan formal kejuruan pada jenjang pendidikan menengah. SMK merupakan pendidikan menengah kejuruan sebagai lanjutan SMP/ MTs atau bentuk lain yang sederajat/diakui sama/setara SMP atau MTs. SMK adalah lembaga pendidikan kejuruan yang tujuan utamanya mempersiapkan siswa menjadi tenaga kerja yang andal. Oleh karena itu lulusan SMK diharapkan tidak hanya bekerja di industri saja tetapi dapat mengembangkan potensi dalam 
dirinya untuk bekerja mandiri (wirausaha) sehingga dapat menciptakan lapangan pekerjaan baru.

\section{Pengaruh Kemampuan Berkomunikasi Terhadap Minat Wirausaha}

Dari hasil penelitian didapatkan bahwa variabel kemampuan berkomunikasi memiliki pengaruh secara parsial terhadap minat wirausaha SMK Negeri Surabaya, hal ini dapat diketahui dari nilai thitung sebesar 5.513 lebih besar dari tabel sebesar 1.99167 maka $\mathrm{H}_{0}$ ditolak pada tingkat signifikansi 5\% sehingga kesimpulannya adalah variabel Kemampuan Berkomunikasi $\left(\mathrm{X}_{2}\right)$ mempunyai Pengaruh signifikan positif terhadap Minat Wirausaha di SMK Negeri Surabaya. Hal ini menunjukkan bahwa semakin tinggi Minat Wirausaha siswa yang ditunjukkan melalui Kemampuan Berkomunikasi yang efektif dan efisien dimana dimana tujuan program keahlian administrasi perkantoran membekali peserta didik dengan keterampilan, pengetahuan dan sikap agar siswa memiliki kompetensi sesuai dengan standar kompetensi lulusan SMK di mana didalamnya terkandung unsur mampu berkomunikasi dalam hal ini mampu menerapkan dan mengembangkan kemampuan berkomunikasi baik lisan maupun tertulis dengan relasi dengan memperhatikan norma dan lingkungan masyarakat, mampu menerapkan dan mengembangkan pelayanan terhadap relasi sehingga diperoleh manfaat masing-masing pihak, mampu berkomunikasi lisan dan tulisan secara efektif dan santun, serta mampu menunjukkan keterampilan menyimak, membaca, menulis, dan berbicara dalam bahasa Indonesia dan Inggris, dengan demikian maka dapat ditarik kesimpulan kemampuan berkomunikasi mmpengaruhi minat wirausaha.

Hasil studi ini sesuai dengan pendapat Arif Ikhsanudin (2012) yang membuktikan Pengaruh Komunikasi Interpersonal dan Lingkungan Keluarga Terhadap Intensi Berwirausaha Siswa SMK Muhammadiyah 3 Yogyakarta. Hal tersebut menunjukkan bahwa seorang wirausaha harus mempunyai nilainilai dan jiwa wirausaha yang ada pada dirinya, seperti mampu membaca peluang yang ada, menciptakan kegiatan usaha, dan memiliki keberanian dalam mengambil risiko dengan kemampuan yang dimilikinya. Selain itu seorang wirausaha memiliki beberapa ciri-ciri, fungsi dan peran sebagai seorang yang percaya diri, inisiatif, berprestasi, jiwa kepemimpinan dan berani mengambil risiko. Sehingga seorang wirausahawan memiliki suatu tantangan untuk memunculkan ide-ide baru dan jiwa yang tangguh agar menjadi seorang wirausawan yang berhasil, dengan demikian maka sikap wirausaha memberi dampak positif untuk menumbuhkan minat dalam berwirausaha.

Hasil studi ini juga sesuai dengan teori Murphy and Peck (Alma, 2013) yang menggambarkan delapan anak tangga untuk mencapai puncak karir. Delapan anak tangga ini dapat pula digunakan oleh seorang wirausaha dalam mengembangkan profesinya, yaitu: mau bekerja keras, bekerja sama dengan orang lain, penampilan yang baik, yakin, pandai membuat keputusan, mau menambah ilmu pengetahuan, ambisi untuk maju dan pandai berkomunikasi. Pandai berkomunikasi berarti pandai mengorganisasi buah pikiran ke dalam bentuk ucapan yang jelas, menggunakan tutur kata yang enak didengar, mampu menarik perhatian orang lain. Komunikasi baik, diikuti dengan perilaku jujur, konsisten dalam pembicaraan akan sangat membantu seseorang dalam mengembangkan karir masa depannya. Akhirnya dengan keterampilan 
berkomunikasi itu seseorang dapat mencapai puncak karir, meraih kursi empuk yang menjadi idaman setiap orang.

\section{Pengaruh Sikap Wirausaha Terhadap Minat Wirausaha}

Dari hasil penelitian didapatkan bahwa variabel Sikap Wirausaha memiliki Pengaruh secara parsial terhadap Minat Wirausaha SMK Negeri Surabaya, hal ini dapat diketahui dari nilai thitung sebesar 7.427 lebih besar dari tabel sebesar 1.99167 maka $\mathrm{H}_{0}$ ditolak pada tingkat signifikansi 5\% sehingga kesimpulannya adalah variabel Sikap Wirausaha $\left(\mathrm{X}_{2}\right)$ mempunyai Pengaruh signifikan positif terhadap Minat Wirausaha di SMK Negeri Surabaya. Hal ini menunjukkan bahwa semakin tinggi Minat Wirausaha siswa yang ditunjukkan melalui Sikap Wirausaha yang kondusif dimana hal tersebut sesuai dengan pendapat beberapa ahli wirausaha merupakan orang-.orang yang mempunyai nilai-nilai dan jiwa wirausaha yang ada pada dirinya, seperti mampu membaca peluang yang ada, menciptakan kegiatan usaha, dan memiliki keberanian dalam mengambil risiko dengan kemampuan yang dimilikinya. Selain itu seorang wirausaha memiliki beberapa ciri-ciri, fungsi dan peran sebagai seorang yang percaya diri, inisiatif, berprestasi, jiwa kepemimpinan dan berani mengambil risiko. Sehingga seorang wirausahawan memiliki suatu tantangan untuk memunculkan ide-ide baru dan jiwa yang tangguh agar menjadi seorang wirausawan yang berhasil, dengan demikian maka dapat ditarik kesimpulan bahwa sikap wirausaha mempengaruhi minat wirausaha.

Hasil dalam penelitian ini sesuai penelitian yang dilakukan oleh Aprilianty (2012), Pengaruh Potensi Kepribadian Wirausaha, Pengetahuan, dun Lingkungan Terhadap Minat Berwirausaha Siswa SMK Rumpun Pertanian di Daerah Istimewa Yogyakarta, menunjukkan bahwa kepribadian wirausaha, pengetahuan, dan lingkungan berpengaruh terhadap minat berwirausaha.

\section{SIMPULAN}

Berdasarkan hasil penelitian dan pembahasan dapat ditarik kesimpulan guna menjawab rumusan masalah yaitu hasil belajar mata pelajaran produktif tidak mempunyai pengaruh signifikan positif secara parsial terhadap minat wirausaha siswa Kelas XI Administrasi Perkantoran Jurusan Administrasi Perkantoran SMK Negeri Surabaya. Hal ini menunjukkan bahwa semakin tinggi hasil belajar yang dimiliki oleh siswa maka belum tentu meningkatkan minat wirausaha siswa SMK Negeri. Kemampuan berkomunikasi berpengaruh signifikan terhadap minat wirausaha siswa Kelas XI Administrasi Perkantoran Jurusan Administrasi Perkantoran SMK Negeri Surabaya. Sikap wirausaha berpengaruh signifikan terhadap minat wirausaha siswa Kelas XI Administrasi Perkantoran Jurusan Administrasi Perkantoran SMK Negeri Surabaya. Pengaruh hasil belajar mata pelajaran produktif, kemampuan berkomunikasi dan sikap wirausaha terhadap minat wirausaha siswa Kelas XI Administrasi Perkantoran Jurusan Administrasi Perkantoran SMK Negeri Surabaya signifikan. Dan ternyata hasil belajar mata pelajaran produktif, kemampuan berkomunikasi dan sikap wirausaha berpengaruh terhadap minat wirausaha siswa Kelas XI Administrasi Perkantoran Jurusan Administrasi Perkantoran SMK Negeri Surabaya. 


\section{DAFTAR PUSTAKA}

Aprilianty, Eka. 2012. Pengaruh Potensi Kepribadian Wirausaha, Pengetahuan, dan Lingkungan Terhadap Minat Berwirausaha Siswa SMK Rumpun Pertanian di Daerah Istimewa Yogyakarta.

Alma, Buchari. 2013. Kewirausahaan. Bandung: Alfabeta.

BPS, 2013 . Statistik Indonesia. Jakarta.

Ikhsanudin, Arif. (2012 Pengaruh Komunikasi Interpersonal dan Lingkungan Keluarga Terhadap Intensi Berwirausaha Siswa SMK Muhammadiyah 3 Yogyakarta.

Riduwan. (2008). Belajar Mudah Penelitian untuk Guru Karyawan dan Peneliti Pemula. Bandung: CV Alfabeta.

Saiman, Leonardus. 2009. Kewirausahaan. Teori, Praktik, dan kasus-kasus. Jakarta: Salemba Empat.

Santosa, Purbayu Budi dan Ashari. (2005). Analisis Statistik dengan Microsoft Excel dan SPSS'. Yogyakarta: ANDI OFFSET.

Sandjaya, H. 2006. Panduan Penelitian. Jakarta: Prestasi Pustaka.

Slameto. 2010. Belajar dan Faktor-faktor yang Mempengaruhinya. Jakarta: Rineka Cipta.

Sudjana, Nana. 1989. Dasar-dasar Proses Belajar Mengajar. Bandung : Sinar Baru Algensido Offset

Sugiyono. 2008. Metode Penelitian Administrasi Dilengkapi dengan Metode $R \& D$. Bandung: CV. ALFABETA.

Sugiyono. 2011. Metode Penelitian Administrasi Dilengkapi dengan Metode $R \& D$. Bandung: CV. ALFABETA. .

Sukardi, Dewa Ketut . 1998. Pendidikan Konseling dalam Bimbingan Karir.Jakarta: Ghalia Indonesia 